\title{
SOUTH AFRICAN OWNED “KIL” CLASS SHIPS
}

\section{Commander W.H. Rice *}

With the First World War came the "Submarine Menace." U-Boats wrought havoc in the shipping lanes around the British coast and the Royal Navy was faced with the task of locating and destroying a hidden foe. In the early days of the war the principal method of attacking UBoats was to lure them to the surface where their thin hulls were vulnerable to the four inch and larger guns mounted aboard naval vessels.

This stratagem gave rise to the " $Q$ " Ship, a vessel looking, to all intents and purposes, like a defenceless merchantman but which, in fact, had hidden armament to be uncovered and brought to bear as soon as a submarine surfaced for the attack. Some "Q" ships were converted merchantmen while others were built as warships but designed to resemble cargo vessels. Their success was limited because U-Boat commanders realising the dangers inherent in a surface attack, began sinking merchant vessels by torpedo without prior warning. Some U-Boat captains, however, remained reluctant to expend their valuable torpedoes on small targets and continued to attack coasters by gunfire.

\section{Development of the Hydrophone}

The development of the hydrophone, which detects the noise emitted by bodies under water, provided a means of locating submerged U-Boats. Some successes were recorded, the first being against UC 7 which was detected by hydrophones and destroyed by depth charges on 6 July 1916. In order to counter the threat posed by U-Boats the Royal Navy built several trawler and patrol gunboat types fitted with hydrophones and armed with depth charges and guns to protect convoys against U-Boats, whether on the surface or submerged. Towards the end of 1917 the "KIL" class Gunboats, named after villages in Scotland and Ireland, and equipped either for antisubmarine patrol or minesweeping, made their appearance. Orders for 85 had been placed earlier that year with 6 shipyards and contracts for the construction of anti-submarine trawlers were cancelled in order to vacate building berths for them.

They were strange looking ships, double ended in appearance with a single funnel amidships and similar shaped deckhouses forward and aft. The single mast was situated as close as possible to amidships and the ship was painted overall with a "Dazzle Pattern" camouflage scheme. This was introduced in May 1917, after it had been developed and perfected by a well known marine artist, Lt. Norman Wilkinson
RNVR. The overall effect of this weird appearance was to make it very difficult for a U-Boat commander to determine which way the patrol ship was heading without exposing his periscope for a dangerously long time. Single screw steamships, they were powered by a three cylinder triple-expansion engine developing 94 Horsepower (Nominal). The cylinders had bores measuring 16", 22 " and 44" respectively and the stroke of the pistons was $26 "$. Steam at a pressure of 200 pounds per square inch was supplied by a single coal fired Scotch boiler.

\section{Too Late for Wartime Service}

Just how successful the "KIL" Ships were as anti-submarine vessels is not known because by the time they were entering service, the worst of the submarine threat, which began to decline with rising U-Boat losses in May 1917 , had passed. Although the construction time was short, about six months from keel-laying to completion, only thirty eight of the eighty five ships ordered had been completed by the Armistice in November 1918. Those of the class in service at the end of the war were put into reserve and were laid up in ports and estuaries around the British Isles. During 1919 they were joined by others, straight from the builders yards, to await disposal. When the Admiralty offered them for sale the "KIL" ships were eagerly taken by shipowners anxious to replace vessels lost during the war. On 14 February 1920 alone, forty eight ships of this class were sold to two civilian owners.

The task of converting the erstwhile patrol vessels to cargo carriers was a fairly simple one. Once the radio mast, four inch (or four-pointseven inch) gun and the signal house (situated aft of the funnel and built to resemble a second bridge) had been removed, it was a fairly simple matter to cut cargo hatches in the upper deck and to provide masts and derricks for cargo handling. Within a short time a patrol gunboat could be converted to a 10 knot coaster of 490 tons deadweight, having one large hold forward and a small one aft.

Shipbuilders and ship repairers, J.Samuel White \& Co. converted eight "KIL" ships to cargo carriers at their shipyard at Cowes, on the Isle of Wight. After conversion these eight ships differed from the rest of the class in two ways. First of all they had straightened stems, and secondly, they were fitted with raised or "topgallant" forecastles. Two others were cut just forward of the bridge and were lengthened from 
182 feet to 213,5 feet, allowing room for an additional small hold.

\section{Peacetime use}

The Kerguelen Whaling and Sealing Co. Ltd, managed by Irvin and Johnson Ltd. of Cape Town bought KILDALKEY and KILFENORA in 1920. Both were completed in 1918 by shipyards on the North East coast of England and both had undergone the "basic" conversion to provide one hold forward and one aft. Both retained their original names and were used to support the company's sealing operations based at the islands of Bouvet and Kerguelen. On the outward voyage they carried supplies for the sealing bases and on the return trip to Cape Town, seal meat, skins and oil.

The world wide depression of the 1930's hit the sealing industry very hard indeed and both were laid up in Saldanha Bay, together with several other unemployed ships.

Both eventually met their fate aground and abandoned in Saldanha Bay. KILDALKEY went ashore near Donkergat in 1937 and KILFENORA landed up on Schapen Island in 1940.

In 1927, Smith's Coasters of Durban bought two converted "KIL" ships which had previously served in the British coastal trade. HOMEFORD, built in 1918 as KILLYGORDON, was one of thirty eight bought in 1920 by Robinson, Brown \& Joplin Ltd. of Newcastle, who operated the largest fleet of "KIL" Ships. They did not keep her more than a few months and, for some reason, did not change her name to suit their policy of naming ships after occupations such as "Crofter," "Sorcerer," "Falconer" and "Bombardier." Instead she was sold to the Homeland SS Co., also of Newcastle who renamed her HOMEFORD.

She was later sold to the Beadon Line Ltd. Although managed by W.H.Kelnyak Ltd. of Cardiff, she retained Newcastle as her Port of Registry. The Beadon Line sold the ship, still named HOMEFORD, to J. Crass, of Newcastle who sold her to Smith's Coasters (Pty) Ltd. in 1927.

MEAD, the other ship purchased by Smith's in that year, was built by Smith's Dock Co. Ltd of Middlesborough, who also built KILFENORA and KILLYGORDON. Although she was launched on 1 May 1919 as KILMEAD, there is no mention of this name in Lloyds Register of $1924 / 5$.

MEAD was one of the ships to emerge from the warship to merchant ship conversion with a straightened stem and a raised forecastle. She was first owned by Llewellyn Gueret of London who operated a fleet of ten converted KIL ships around the British Coast. After some years she was purchased from Gueret by Charles Louis Storm, of Durban, who sold her within a few months to Smith's Coasters. With HOMEFORD she was employed in the coastal trade carrying sugar from Durban to Port Elizabeth and returning with general cargo. From time to time the trade took them as far afield as Cape Town, and in 1938 HOMEFORD called in at Knysna on the way.

\section{Second World War}

On 5 May 1942 MEAD, a warship completed too late for the war for which she was intended, was requisitioned by the British Admiralty to serve in the following one. Her conversion to a cable layer was completed on 21 December 1942 and, as HMS MEAD, she was used to lay cables for the controlled minefields and degaussing ranges at Cape Town and Durban and also in Saldanha Bay.

On 27 August 1944 she was taken over by the South African Naval Forces and was recommissioned as HMSAS MEAD. Members of her ship's company were awarded one Decoration and two Mentions in Despatches as a result of her wartime activities and she was awarded the Battle Honour "South African Waters."

\section{Final Years}

After the war ended HMSAS MEAD was employed for several months undoing the work she had done previously. The heavy cables she had laid contained valuable copper and lead which had to be recovered and returned to the UK for scrap. On being "demobbed" she spent fourteen months in the hands of ship repairers Gilbert Hamer \& Co. of Durban, being in drydock for four of those months.

HOMEFORD remained in the coastal trade for much of the war but ranged far afield on occasions. One of her wartime tasks was to carry drums of oil from the British Naval Base at Mombassa to the Lighthouse at Cape Guardafui, at the entrance to the Red.Sea. She also supported Allied landings on the coasts of Somalia and Madagascar before being released from war service.

In 1946 Smith's Coasters decided that they had no further use for the twenty eight year old HOMEFORD and sold her to Gilbert Vallance Webb who, a few months later, sold her to the Arden Hall Steamship Co. Ltd of Cape Town. The ship traded under the name LAEVELD on their service to the Indian Ocean islands until 1951 when she was bought by another local firm, Dent and Goodwin. Soon afterwards she changed hands again, being bought by a 


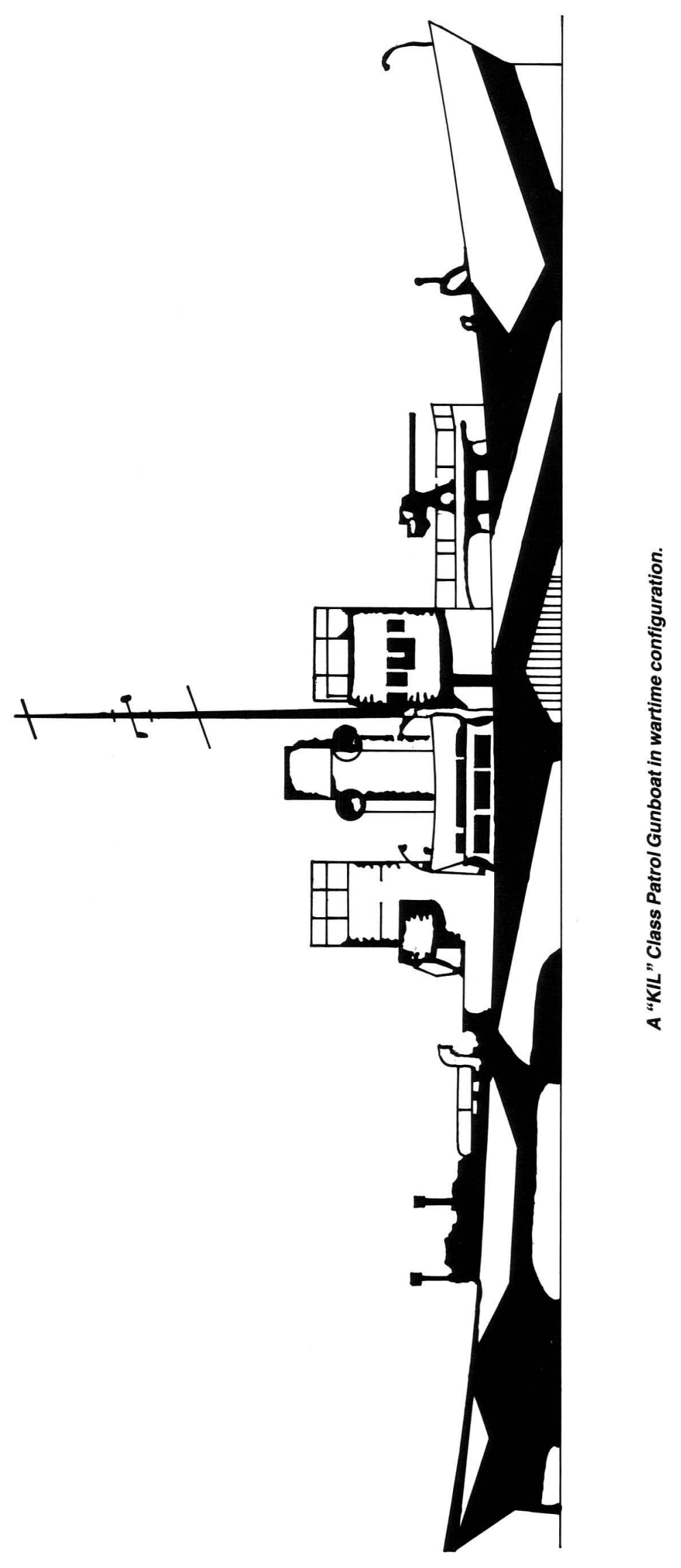


Greek shipowner, B. Nikolau, who changed her name to ELEOUSSA and her flag to that of Panama.

In December 1955 the magazine "Ships and Ship Models" stated that there were only three former "KIL" ships remaining in service throughout the world. These were, according to the magazine, the British registered BRITANNIA (ex KILINNEY, the Greek STEFANOS (ex KILBURN) and the ELEOUSSA (ex HOMEFORD ex KILLYGORDON), said to be registered in Costa Rica. MEAD, which was still trading at that time was not included on the list because Lloyds Register did not record the fact that she had been launched as a "KIL" ship and, therefore, she was not recognised as being a member of the class.

MEAD, having emerged considerably modernised from her long refit in 1947, spent the next ten years sailing under the Smith's Coasters houseflag on the route she had served before the war. In 1957 she was sold to another Durban Company, the Point Shipping Co. (Pty) Ltd. It is understood that this company originally chose the name PONGOLA for their new ship but, for some reason. were not able to use it and named her KOMATI instead. She traded between Durban and Mozambique for her new owners and, from 1958 onwards for Durban Lines, who took her over without changing her name.

On 18 March 1960, KOMATI (ex MEAD ex KILMEAD) was sold to K.Nathan (Pty) Ltd. for demolition at Durban.

ELEOUSSA changed hands in 1958, being bought by another Greek owner who renamed her PANAGHIA TINOU. Between 1961 and 1963 she bore the name PANAGHIA ODOHI-
TRIA but then reverted to PANAGHIA TINOU under the ownership of $J$ Meleas: J Constananeas \& Co, also of Greece.

PANAGHIA TINOU, the sole survivor of the eighty five "KIL" Class Gunboats ordered in World War 1, met her end on 8 October 1964 when she ran aground on the Italian Coast at Velirat, near Trieste. The hull broke in two and became a total loss but, fortunately, the crew was saved.

This, then, is the story of KILDALKEY, KILFENORA, KILLYGORDON, and KILMEAD, four small ships which arrived on the scene too late to play a part in the war for which they were built. Converted to merchant ships they played a vital part in re-establishing maritime trade in the post-war period. All four played an important part in consolidating the South African coastal shipping industry and two of them went on to serve in the Second World War and the post war reconstruction period to achieve a total service life in excess of 40 years.

* Commander W.H. Rice is Chief of the Engineering Bureau, Strike Craft.

\section{BIBLIOGRAPHY}

1. Salt in my Blood - George Young. J.F.Midgeley/G.Young - Kommetjie 1975.

2. South African Merchant Ships - B.D.Ingpen. A.A.Balkema - Cape Town/Rotterdam.

3. Warships of World War I - H.M. Ie Fleming. Ian Allan.

4. British Warships 1914-1919 - Dittmar and Colledge. Knysna.

5. The Forgotten Port - Margaret Parkes and V.M.Williams. Emu Publishers Knysna 1988.

6. South African Naval Forces 1939-1945 - Cdr. W.M.Bisset, S.A.Navy

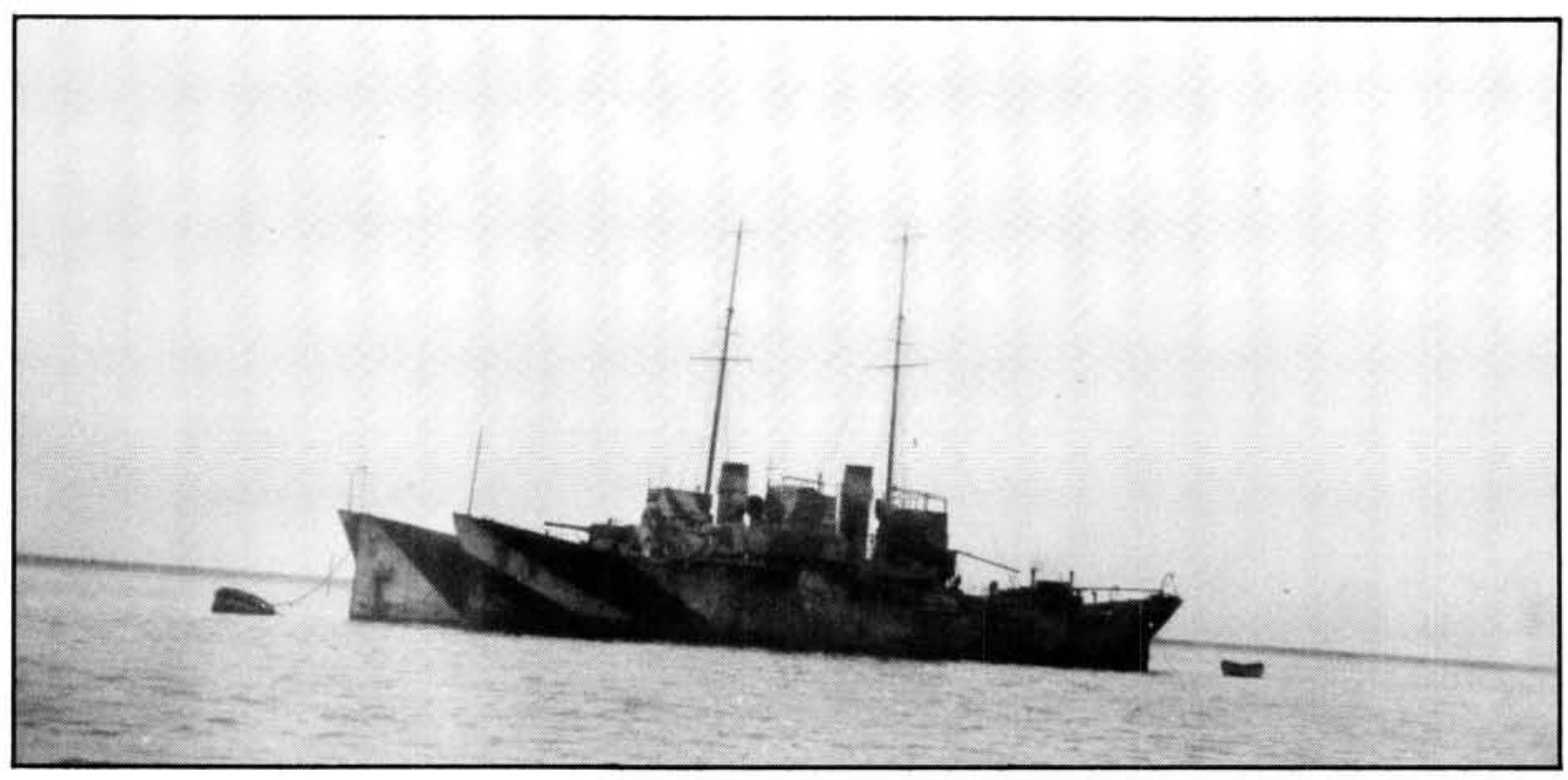

“KIL" Class Ships laid up in the River Medway in 1919. Photo: The Willis Collection: Simon's Town Museum. 


\begin{tabular}{|c|c|c|}
\hline NAME & BUILDER & HISTORY \\
\hline $\begin{array}{l}\text { KILFENORA } \\
\text { (Admiralty } \\
\text { No.3802) }\end{array}$ & Smith's Dock Middlesborough & $\begin{array}{l}\text { 14/1/1917 Launched. } \\
\text { 14/2/20 Sold to Robinson, Brown \& Joplin Ltd. } \\
\text { of Newcastle } \\
1920 \text { Resold to Kerguelen Sealing \& Whaling } \\
\text { Co. Ltd. (I \& J Managers). } \\
\text { 1940 - Wrecked on Schapen island, Saldanha } \\
\text { Bay. }\end{array}$ \\
\hline $\begin{array}{l}\text { KILDALKEY } \\
\text { (Admiralty } \\
\text { No.4027) }\end{array}$ & $\begin{array}{l}\text { Cochrane \& Co. Ltd. Selby } \\
\text { Yorks. }\end{array}$ & $\begin{array}{l}\text { 13/3/1918 Launched } \\
\text { 14/2/20 Sold to Robinson, Brown \& Joplin Ltd. } \\
\text { of Newcastle } \\
1920 \text { Resold to Kerguelen Sealing \& Whaling } \\
\text { Co. Ltd. (I \& J Managers). } \\
\text { 1937 - Wrecked near Donkergat, Saldanha } \\
\text { Bay. }\end{array}$ \\
\hline $\begin{array}{l}\text { KILLYGORDON } \\
\text { (Admiralty } \\
\text { No. } 4055 \text { ) }\end{array}$ & Smith'a Dock Middlesborough & $\begin{array}{l}\text { 10/10/1918 Launched } \\
14 / 2 / 20 \text { Sold to Robinson, Brown \& Joplin Ltd. } \\
1920 \text { - Resold to Homeland SS Co Ltd. } \\
\text { Renamed HOMEFORD. } \\
\text { Sold to Beadon Line (W.H Kelnyack Man- } \\
\text { agers). } \\
\text { Sold to J.Crass. } \\
1927 \text { - Sold to Smith's Coasters (Pty) Ltd. Dur- } \\
\text { ban. } \\
1946 \text { - Sold to Gilbert Vallance Webb. } \\
1947 \text { - Resold to Arden Hall Steamship Co. } \\
\text { Ltd. and renamed LAEVELD. } \\
1951 \text { - Sold to Dent \& Goodwin } \\
1952 \text { - Sold to B. Nikolau and renamed } \\
\text { ELEOUSSA. Registered in Panama. } \\
1955 \text { - Registered in Costa Rica. } \\
1958 \text { - Sold to S. Yianniouli and renamed } \\
\text { PANAGHIA TINOU. } \\
\text { 1961 - Renamed PANAGHIA ODOHITRIA. } \\
1963 \text { - Renamed PANAGHIA TINOU Owned by } \\
\text { J. Meleas; J. Constaneas \& Co. } \\
1964 \text { - Ran aground on } 8 \text { October near Velirat, } \\
\text { on the Italian Coast (near Trieste) and broke in } \\
\text { two. The crew was rescued. }\end{array}$ \\
\hline $\begin{array}{l}\text { KILMEAD } \\
\text { (Admiralty } \\
\text { No.4063) }\end{array}$ & Smith's Dock Middlesborough & $\begin{array}{l}\text { 1/51919 Launched } \\
14 / 2 / 20 \text { Sold to L. Gueret \& Co. Ltd. London } \\
\text { and renamed MEAD. } \\
1927 \text { - Sold to Charles Louis Storm, of Durban. } \\
1927 \text { - Resold to Smiths' Coasters (Pty) Ltd. of } \\
\text { Durban. } \\
1942 \text { - Taken up by British Admiralty and con- } \\
\text { verted for cable laying. Conversion completed } \\
21 / 12 / 42 \text {. } \\
1944 \text { - transferred to SANF and Commissioned } \\
\text { as HMSAS MEAD. } \\
1946 \text { - Refitted and modernised by Gilbert } \\
\text { Hamer (Pty) Ltd at Durban } \\
1947 \text { - Returned to coastal trade. } \\
1957 \text { - Sold to Point Shipping Co. (Pty Ltd. and } \\
\text { renamed KOMATI. } \\
1959 \text { - Sold to Durban Lines (Pty) Ltd. } \\
1960 \text { - Sold to K. Nathan (Pty) Ltd. on } 18 \\
\text { March for demolition at Durban. }\end{array}$ \\
\hline
\end{tabular}




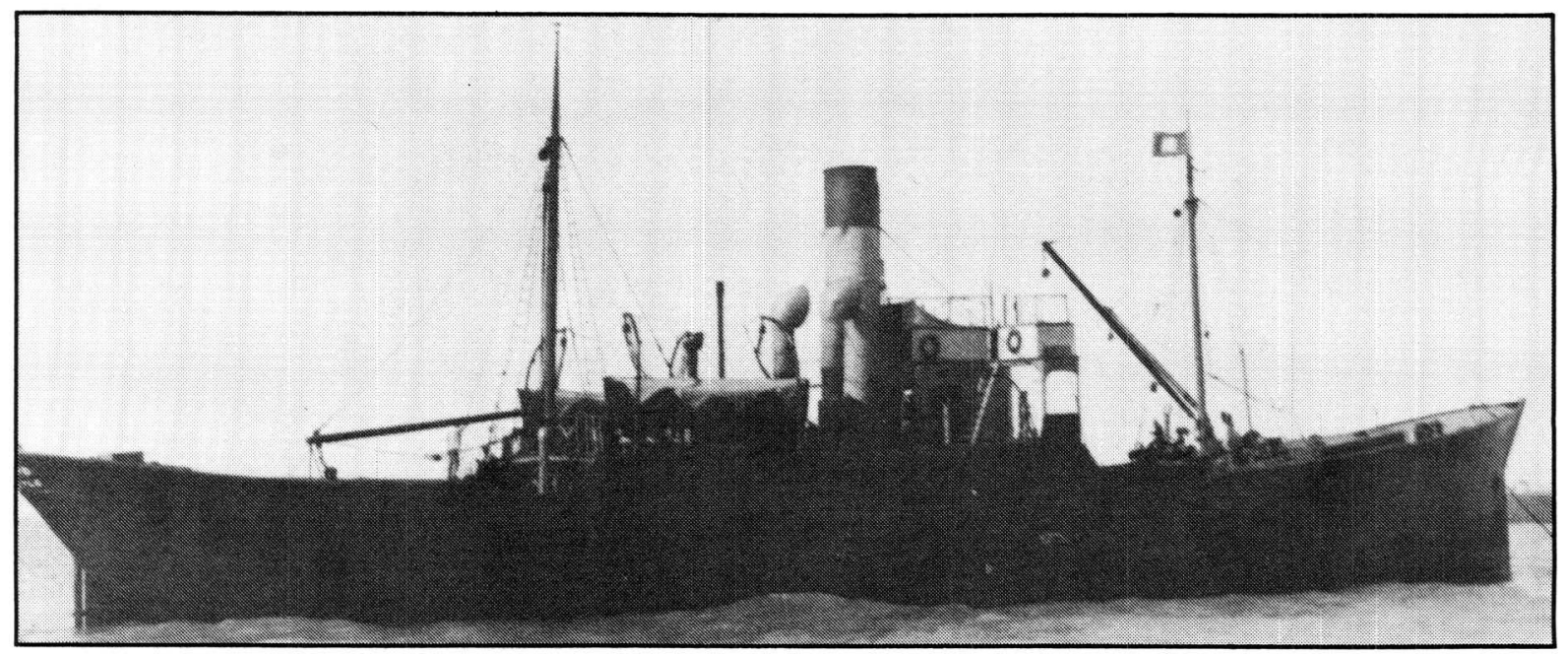

S.S. HOMEFORD (ex KILL YGORDON) in Smith's Coasters (Pty) Ltd livery. Photo: David Hughes.

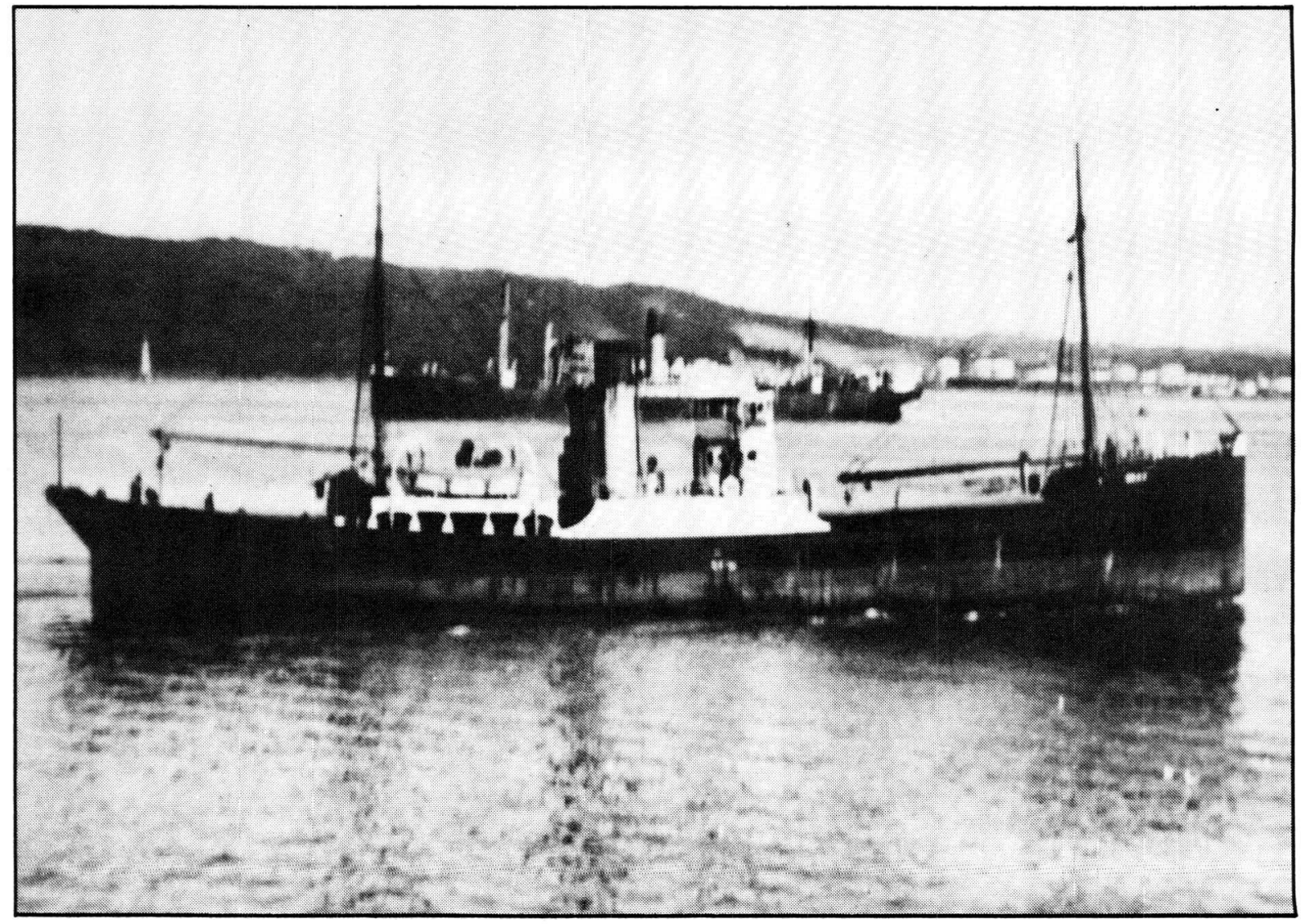

S.S. MEAD (ex KILMEAD) in Smith's Coasters (Pty) Ltd livery. Photo: David Hughes. 